\title{
An experimental study on change of gas permeability depending on pore structures in three species (hinoki, Douglas fir, and hemlock) of softwood
}

\author{
Eun-Suk Jang ${ }^{1}$, Jee-Hoon Yuk ${ }^{2}$ and Chun-Won Kang ${ }^{1^{*}}$ (i)
}

\begin{abstract}
The purpose of this study is to analyze the pore structure for the heartwood, intermediate wood, and sapwood sections in three species of softwood (hinoki, Douglas fir, and hemlock) and to investigate the correlation of gas permeability depending on pore structure. For this study, gas permeability and pore size were measured by capillary flow porometry, and classification of a novel method was performed to determine the type of pores (through pores, blind pores, and closed pores) based on International Union of Pure and Applied Chemistry (IUPAC). Gas permeability, through pore porosity, and pore size increased from heartwood to sapwood. The results of multiple regression analysis showed that through pore porosity, mean pore size, and bulk density were significant factors affecting gas permeability.
\end{abstract}

Keywords: Heartwood, Sapwood, Through pore, Blind pore, Closed pore, Capillary flow porometry, Gas pycnometry, Gas permeability, Hinoki, Douglas fir, Hemlock

\section{Introduction}

The permeability of wood greatly influences drying rate because free water moves to the surface layer by capillary flow at the beginning of drying [1]. High-temperature and high-frequency drying methods generate water vapor that can move rapidly through the capillary passage [2].

In recent research, permeability of wood is recognized as an important parameter in various applications such as heat-treated wood [3-5], nanomaterial impregnation [6-8] and use of the transverse surface of wood as a porous sound-absorbing material [9-11]

\footnotetext{
*Correspondence: kcwon@jbnu.ac.kr

${ }^{1}$ Department of Housing Environmental Design, and Research Institute

of Human Ecology, College of Human Ecology, Jeonbuk National

University, Jeonju 54896, South Korea

Full list of author information is available at the end of the article
}

Applying an appropriate drying schedule can improve the permeability of wood $[12,13]$. Impregnation of aqueous metal nanoparticles into heat-treated solid woods can improve its permeability because some of the wood's extractives dissolve, producing perforations and pits [14]. Further, heat treatment of wood increases the permeability of wood due to loss of bound water, shrinkage at low temperatures, and physicochemical changes of cell walls at high temperatures [15].

Thus, improving the permeability of wood has the advantages of drying defects, impregnation of chemicals, and sound absorption performance $[3,10,11,13,16,17]$.

As the diameter of a tree reaches a certain level during the growth process, the color between the inside and the outside of the cross-section appears different. The dark part of the inside is called heartwood and the light part of the outside is called sapwood [18].

Sapwood is a living tissue that acts as a pathway for water and nutrients. It contains a high level of moisture
Springer Open
C The Author(s) 2020. This article is licensed under a Creative Commons Attribution 4.0 International License, which permits use, sharing, adaptation, distribution and reproduction in any medium or format, as long as you give appropriate credit to the original author(s) and the source, provide a link to the Creative Commons licence, and indicate if changes were made. The images or other third party material in this article are included in the article's Creative Commons licence, unless indicated otherwise in a credit line to the material. If material is not included in the article's Creative Commons licence and your intended use is not permitted by statutory regulation or exceeds the permitted use, you will need to obtain permission directly from the copyright holder. To view a copy of this licence, visit http://creativecommons.org/licenses/by/4.0/. 
and comprised a soft texture. But heartwood is composed of dead cells with no physiological dysfunction and a low level of moisture content [19].

Over the years, many researches have reported that sapwood has greater gas permeability than heartwood [20-23] due to the difference in chemical and anatomical characteristics [24].

From a chemical point of view, cellulose and holocellulose (a combination of cellulose and hemicellulose) contained in heartwood are generally less abundant than those of softwood [25-28]. It is also known that heartwood has a large amount of extractives [28-30]. The content of the extractives has a significant effect on permeability, resulting in less permeability of heartwood than sapwood and difficulty in drying, impregnating, and using the wood pulp $[25,26,28,30,31]$.

With respect to anatomical characteristics, the main cause of the permeability difference in softwood is extent of closure of the bordered pit pair in heartwood and of the extract deposits accumulated on the pit membrane [32]. Increased permeability in sapwood is attributed to the size and frequency of resin canals and parenchyma rays [33].

The permeability of wood is related to pore structure, which has been investigated using various methods.

Schneider and Wagner reported that the mean pore size of heartwood was smaller than that of softwood as measured by mercury intrusion porometry [34]. Plötze and Niemz reported pore distribution and pore size of 24 wood species using a mercury intrusion porosimeter and classified them as macro-pore, meso-pore, and micro-pore according to pore diameter [35]. Kang et al. [3] reported change in pore size of heat-treated malas (Homalium foetidum) by capillary flow porometry. Jang et al. reported that the pore size varies depending on method, between mercury intrusion porosimetry and capillary flow porometry [36]. Jang et al. [37] classified three pore shapes (through pore, blind pore, and closed pore) in heartwood, intermediate wood, and sapwood of cross-sectional yellow poplar and measured their contents. The results showed that pore size and through pore porosity increased from heartwood to sapwood [37]. In the same way, Jang and Kang analyzed the pore structure of heat-treated woods that are classified into three pore types based on IUPAC. They reported that, as the heat treatment temperature increased, the through pore porosity and pore size also increased [5].

Unlike hardwood, softwood is composed of simple structures referred to as tracheid, and its heartwood is more difficult to dry and impregnate with chemical than that of sapwood, which is commonly known to cause pit aspiration of the tracheid [19]. The tracheid of softwood is considered a type of through pore, while pit aspiration of the tracheid is considered closed pore in accordance with IUPAC's morphological classification.

Pore classification based on IUPAC between heartwood and sapwood was performed in a previous study [37]. However, in the previous study, pore structure was classified for only one species of hardwood (yellow poplar), and no comparison of species was performed. For such a classification to be useful in wood, it needs to be tested in various species. Also, the studies did not clearly demonstrate statistical explanations on how the gas permeability difference correlates with the type of pores in various species of wood. Therefore, this study selected three species of softwood [hinoki (Chamaecyparis obtusa (Siebold \& Zucc.) Endl, Douglas fir (Pseudotsuga menziesii), and hemlock (Tsuga heterophylla)]. In addition, statistical analysis was performed to investigate the correlation between air permeability and pore structure of wood.

Specifically, this study analyzed pore size, gas permeability, and pore type in accordance with IUPAC's morphological classification of pores in three species of softwood. In addition, this study performed statistical analysis on correlations and associations among pore size, pore type, and gas permeability by Pearson correlation analysis and multiple regression.

\section{Materials and methods}

\section{Specimen preparation}

Figure 1 shows three species of softwood purchased from a Korean wood market (Jeonil timber Co., Ltd), 20-year-old hinoki [Chamaecyparis obtusa (Siebold \& Zucc.) Endl] from Japan, 26-year-old Douglas fir (Pseudotsuga menziesii) from North America, and 20-yearold hemlock (Tsuga heterophylla) from North America. The logs were cut into cross-sections with thickness of $1 \mathrm{~cm}$. In hinoki, the entire diameter was $20 \mathrm{~cm}$, and the diameter of the heartwood was $14 \mathrm{~cm}$. The entire diameter of the Douglas fir was $32 \mathrm{~cm}$, and the diameter of the heartwood was $20 \mathrm{~cm}$. In the hemlock, the entire diameter was $29 \mathrm{~cm}$, and the diameter of the heartwood was $20 \mathrm{~cm}$. From the cross-sectional discs, 10 cylindrical specimen (30 mm diameter $\times 10 \mathrm{~mm}$ thickness) of heartwood, intermediate wood, and sapwood were cut. Intermediate wood samples were distinguished by interfacing with approximately $50 \%$ of the area of the heartwood and sapwood. The cylindrical specimens were dried at $40{ }^{\circ} \mathrm{C}$ using a dryer for 1 week and controlled within a $10 \%$ moisture content $(\mathrm{MC})$ to exclude the influence of MC between heartwood and sapwood to focus on pore structure.

To measure the true density of the wood substance, internal voids must be ignored. Wood samples from the 


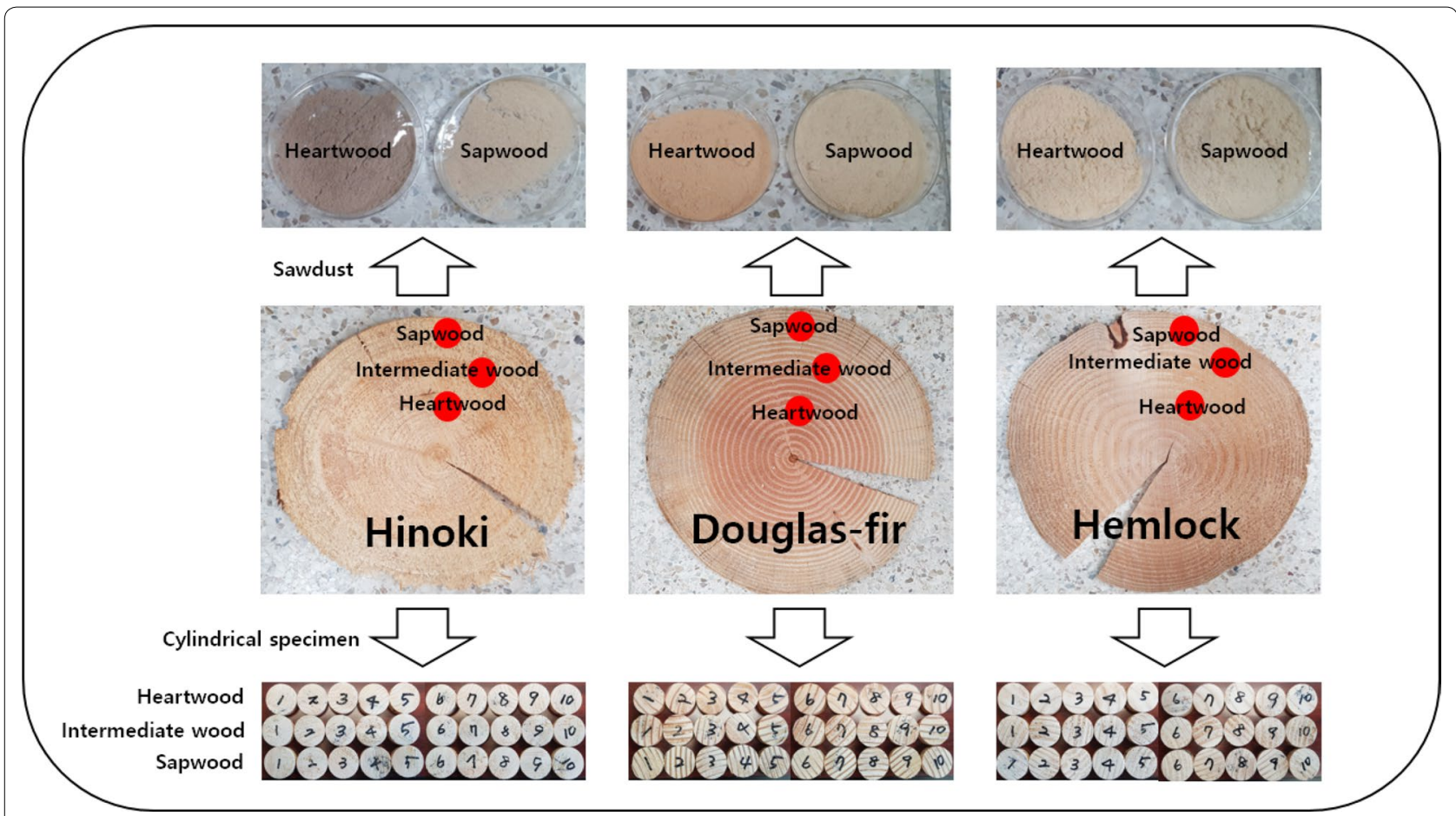

Fig. 1 Preparation of three species of softwood specimens (left: hinoki, middle: Douglas fir, right: hemlock)

sapwood and the heartwood were pulverized into fine wood powder [34, 37, 38].

\section{Scanning electron microscope (SEM) imaging for cross-sections of specimens}

To observe the pore morphology of a specimen, its cross-sections were cut into dimension of approximately $5 \mathrm{~mm}$ (radial) $\times 5 \mathrm{~mm}$ (tangential) $\times 4 \mathrm{~mm}$ (longitudinal), and the surfaces were smoothed using a microtome (model: HM400S, Microm GmbH, Germany). Further, specimens were coated with gold ions by an ion sputtercoater (model: SCM, Emcrafts, Korea) and observed at an acceleration voltage of $13 \mathrm{kV}$ and $400 \times$ magnification using scanning electron microscopy (SEM; model: Genesis-1000, Emcrafts, Korea).

\section{Measurement of bulk density and true density}

Bulk density of the cylindrical specimens was measured by the dimension method. True density of cylindrical specimens and sawdust was measured by gas pycnometer (model: PYC-100A-1, Porous Material Inc., USA) [5, 37, 38]. Before measuring the specimen, the gas pycnometer was calibrated to a standard stainless-steel cylindrical sample from the manufacturer, the volume and mass of which were $15.4346 \mathrm{~cm}^{3}$ and $41.1767 \mathrm{~g}$, respectively. The volumes of the reference chamber and sample chamber were $35.5310 \mathrm{~cm}^{3}$ and $33.5224 \mathrm{~cm}^{3}$, respectively. For convenience, the true density of sawdust intermediate wood was calculated as the average of heartwood and sapwood.

\section{Measurement of gas permeability}

Gas permeability was measured using a capillary flow porometer (model: CFP-1200AEL, Porous Materials, Inc., USA). To prevent air leakage from edge of a cylindrical specimen, the side surface was sealed with a silicon O-ring. Increasing pressure slowly, air flow through the pore was measured, and the Darcy permeability constant was calculated from Eq. (1) shown below:

$$
C=8 \mathrm{FTV} / \pi D^{2}\left(P^{2}-1\right),
$$

where $C$ is the Darcy permeability constant; $F$ is the flow; $T$ is the sample thickness; $V$ is the viscosity of air; $D$ is the sample diameter; and $P$ is the pressure.

\section{Measurement of pore diameter}

Pore diameter of specimens was measured using a capillary flow porometer (model: CFP-1200AEL, Porous Material Inc, USA). The ASTM F316-03 [39] method was used to selectively measure the constricted part of a through pore related with permeability and is widely used for analysis of pore structure of various porous materials [40]. It is also a possible way to selectively 
measure only through pores in line with permeability of wood [36, 37]. As shown in Fig. 2, in the process of gas permeability estimation by flow rate under pressure, the graph of flow rate versus pressure is called a 'dry curve'. Next, the specimens were wetted in Galwick solution that has an extremely low surface tension (surface tension: $0.159 \mathrm{mN} / \mathrm{m}$ ) and non-volatility to penetrate well into the cavity. Pressure was measured sequentially from the moment when the flow rate of the gas was detected with solution extrusion, and the pressure at the time of initial flow increase is called the 'bubble point'. In the wet state, the graph of flow rate versus pressure is called a 'wet curve'. Here, an imaginary curve having a slope of $1 / 2$ of that of the 'dry curve' can be drawn and is called a 'half-dry curve.' The point where the 'wet curve' and 'halfdry curve' meet is called 'mean flow pore pressure', and the pore size is determined by Eq. (2) as below:

$$
D=\frac{C_{\tau}}{p},
$$

where $D$ is the limiting diameter, $\tau$ is the surface tension, $p$ is the pressure, and $C$ is the constant of 2860 when $p$ is in $\mathrm{Pa}, 2.15$ when $p$ is in $\mathrm{cmHg}$, and 0.415 when $p$ is in psi units.

Porosity of through pore, blind pore, and closed pore types Following IUPAC [41], pore types of solid porous materials can be classified as through pores, blind pores, and closed pores (Fig. 3). Hence, this study measured the content of each type of pores in the three species of wood as in previous studies [5,37]. Specifically, content was measured for through pore porosity $\left(\phi_{\text {through }}\right)$, blind pore porosity $\left(\phi_{\text {blind }}\right)$, and closed pore porosity $\left(\phi_{\text {closed }}\right)$ of the cylindrical specimens using the following method.

Total porosity $\phi_{\text {total }}(\%)$ was calculated from Eq. (3) measuring true volume ( $\left.V_{\text {true }}\right)$ of the sawdust by gas pycnometry and bulk volume $\left(V_{\text {bulk }}\right)$ of the cylindrical specimens by the dimensional method:

$$
\phi_{\text {total }}(\%)=\left(1-\frac{V_{\text {true }}}{V_{\text {bulk }}}\right) \times 100 .
$$

Pore volume of the cylindrical specimen by gas pycnometer was obtained as the sum of through pore volume $\left(V_{\text {through }}\right)$ and blind pore volume $\left(V_{\text {blind }}\right)$. Thus, the sum of through pore porosity $\left(\phi_{\text {through }}\right)$ and blind pore porosity $\left(\phi_{\text {blind }}\right)$ was calculated as in Eq. (4):

$$
\phi_{\text {through }}+\phi_{\text {blind }}=\frac{V_{\text {through }}+V_{\text {blind }}}{V_{\text {bulk }}} \times 100 .
$$

Finally, from the results of Eqs. (3) and (4), closed pore porosity $\left(\phi_{\text {closed }}\right)$ was obtained with Eq. (5):

$$
\phi_{\text {closed }}=\phi_{\text {total }}-\left(\phi_{\text {through }}+\phi_{\text {blind }}\right) .
$$

To distinguish through pore porosity ( $\left.\phi_{\text {through }}\right)$ from blind pore porosity $\left(\phi_{\text {blind }}\right)$, this study wetted cylindrical specimens in Galwick solution (surface tension: $0.159 \mathrm{mN} / \mathrm{m}$ ) and intruded the liquid into the pores utilizing a vacuum pump. After that, the specimens were placed in a chamber of which both sides were sealed with O-rings, and the air pressure was increased in the longitudinal direction so that only Galwick in the through

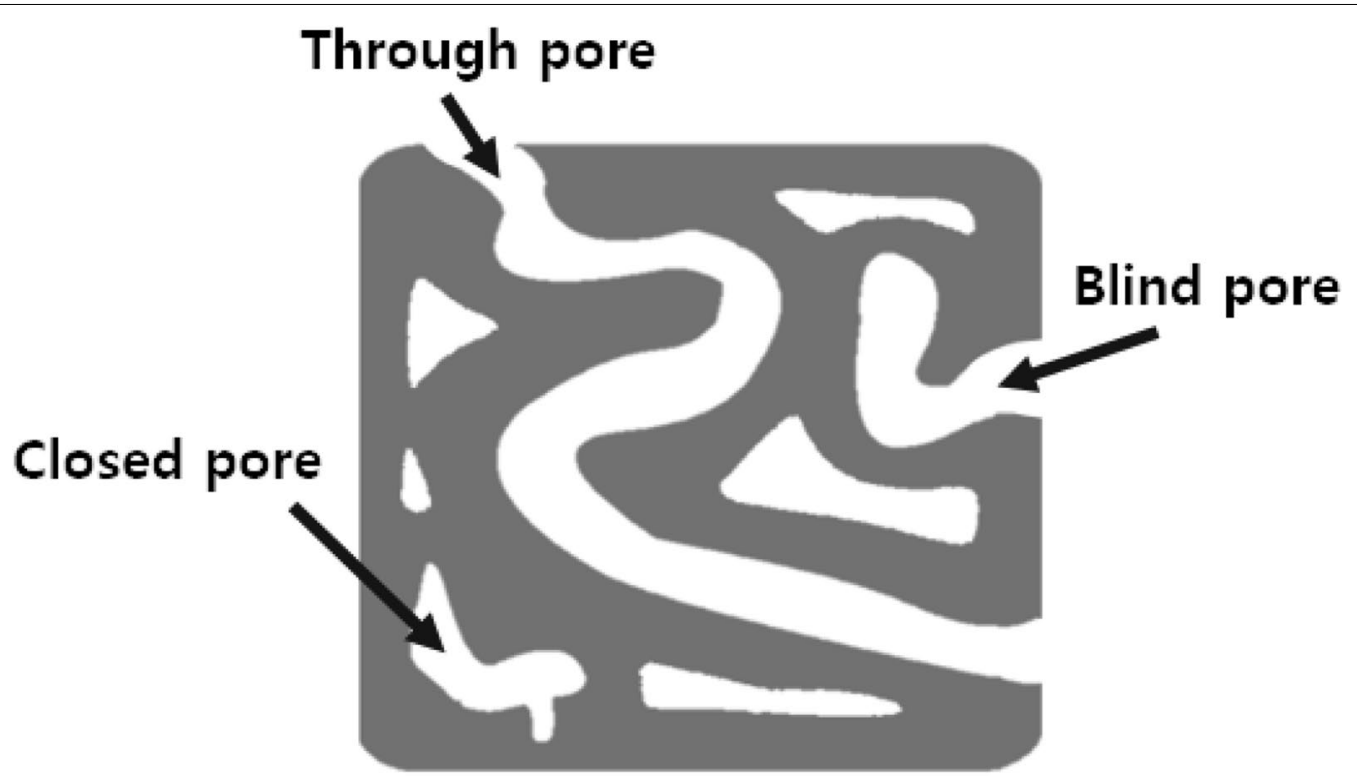

Fig. 2 The schematic illustration of three types of pore in solid porous materials based on IUPAC 


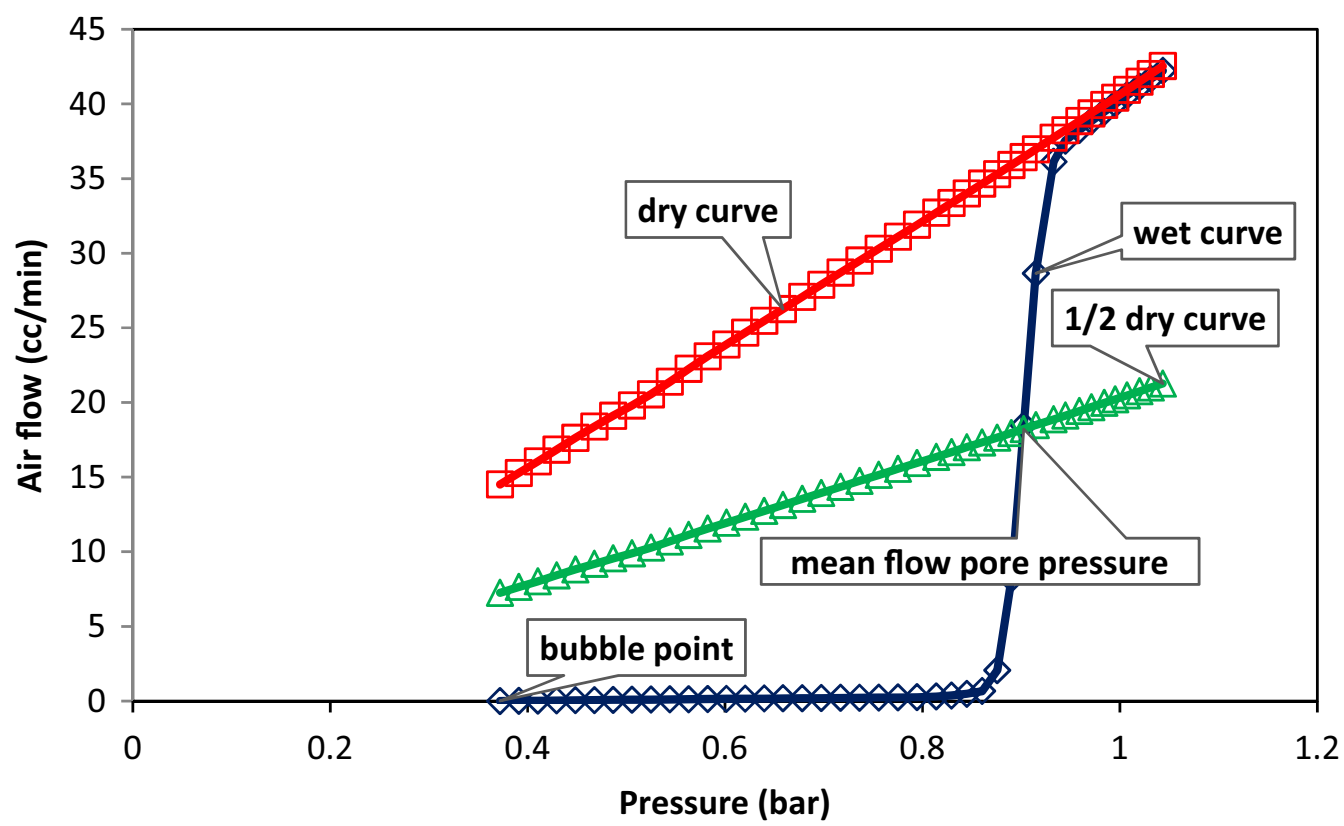

Fig. 3 Principle of capillary flow porometry

pores could be extruded since blind pores were blocked at one end.

We obtained the mass of Galwick solution in blind pores by measuring the difference between specimen mass after extrusion $\left(M_{\text {after extrusion }}\right)$ and dried specimen mass $\left(M_{\text {dried }}\right)$. Also, the volume of blind pore $\left(V_{\text {blind }}\right)$ was calculated as the difference between specimen mass $\left(M_{\text {after extrusion }}-M_{\text {dried }}\right)$ and specific gravity of Galwick solution $\left(\rho_{\text {Galwick }}\right)$ using Eqs. $(6,7$, and 8$)$ :

$$
\begin{aligned}
& V_{\text {blind }}=\frac{M_{\text {after extrusion }}-M_{\text {dried }}}{\rho_{\text {Galwick }}}, \\
& \phi_{\text {blind }}=\frac{V_{\text {blind }}}{V_{\text {bulk }}} \times 100, \\
& \phi_{\text {through }}=\left(\phi_{\text {through }}+\phi_{\text {blind }}\right)-\phi_{\text {blind }} .
\end{aligned}
$$

\section{Statistical analyses}

This study applied a statistical approach to corroborate reliability of the experimental results.

Physical properties (pore type, pore size, and density) of wood can affect gas permeability. Among the three types of pores for solid porous materials defined by IUPAC, only through pores can permit fluid inflow. Thus, through pore porosity may have a significant effect on gas permeability [5, 37]. Moreover, as pore size increases, the flow of fluid generally increases; as density increases, the flow of fluid generally decreases. In short, pore size, bulk density, and through pore porosity are significant factors affecting gas permeability. Thus, this study statistically investigated the effects of through pore porosity, mean pore size, and bulk density on gas permeability.

Specifically, this study compared the average gas permeability, pore size, and porosity of three parts of heartwood, intermediate wood, and sapwood using analysis of variance (ANOVA).

In addition, this study analyzed statistical correlation by Pearson correlation analysis to understand univariate associations among the variables. Furthermore, this study utilized multivariate regression to analyze effects of physical factors on gas permeability to enable investigation of factor-specific effects on dependent variables after controlling the other factors. Multivariate regression has another advantage in that it provides the simultaneous effects of several variables on the dependent variable.

The multivariate regression model was used to display the effects of through pore porosity, mean pore size, and bulk density on gas permeability as displayed in the equation below:

$$
Y=\alpha_{0}+\beta_{1} X_{1}+\beta_{2} X_{2}+\beta_{3} X_{3}+\beta_{4} D_{1}+\beta_{5} D_{2}+\varepsilon,
$$

where $Y$ is the gas permeability; $X_{1}$ is the through pore porosity; $X_{2}$ is the mean pore size; $X_{3}$ is the bulk density; $D_{1}$ is the wood dummy variable (1: if the wood is hinoki, otherwise 0 ); $D_{2}$ is the wood dummy variable (1 
if the wood is Douglas fir, otherwise 0$) ; \alpha_{0}$ is the constant (intercept term); and $\varepsilon$ is the residuals (error term).

This study uses Eq. (9) as an ordinary least square (OLS) regression model that formulates a linear function. Thus, $\alpha_{0}$ in Eq. (9) represents a constant (intercept term) of the linear function model, while $\varepsilon$ indicates residuals (error term) of the regression model. Basically, regression analysis such as Eq. (9) assumes that the expected value of the error term is zero $\left[E\left(\varepsilon_{i}\right)=0\right]$, resulting in an estimated value of 0 (zero) for $\varepsilon$.

If estimated coefficients of $\beta_{1}, \beta_{2}$ and $\beta_{3}$ in Eq. (9) are significant, the three physical properties $\left(X_{1}, X_{2}\right.$, and $\left.X_{3}\right)$ substantially affect gas permeability. Wood dummy variables $\left(D_{1}\right.$ and $\left.D_{2}\right)$ were included in Eq. (9) to control the effect of wood species. Specifically, $D_{1}$ has a value of 1 if the wood is hinoki and 0 (zero) if the woods are other species. Likewise, $D_{2}$ has a value of 1 if the wood is Douglas fir and 0 (zero) if the woods are other species. Therefore, hemlock has a value of 0 (zero) for both $D_{1}$ and $D_{2}$, and those two dummy variables $\left(D_{1}\right.$ and $\left.D_{2}\right)$ control the effect of the difference among the three species of wood. Further, this study analyzes VIF (variance inflation factor) values of all independent variables in Eq. (9) to assess the multi-collinearity among the independent variables. Multi-collinearity is not serious if the estimated VIF value does not exceed 10 .

All sample data were analyzed using both Pearson correlation analysis and regression analysis $(n=90)$. Also, measured values of all variables were winsorized at $2 \%$ of both sides to minimize the effect of extreme values.

All statistical analyses were performed using IBM SPSS statistics v25 software (IBM Corp., Armonk, NY, USA).

\section{Results and discussion SEM observation}

The cross-sectional surface of each specimen is presented in Fig. 4. Earlywood and latewood were observed in every specimen. However, it was difficult to distinguish characteristics of heartwood and sapwood in SEM images.

\section{Results of bulk density and true density}

The average bulk densities of hinoki were $0.47 \mathrm{~g} / \mathrm{cm}^{3}$ (standard deviation, $\mathrm{SD}=0.01$ ) of heartwood, $0.45 \mathrm{~g} /$ $\mathrm{cm}^{3}(\mathrm{SD}=0.01)$ of intermediate wood, and $0.44 \mathrm{~g} / \mathrm{cm}^{3}$ $(\mathrm{SD}=0.01)$ of sapwood. The average bulk densities of Douglas fir were $0.42 \mathrm{~g} / \mathrm{cm}^{3}(\mathrm{SD}=0.02)$ of heartwood, $0.42 \mathrm{~g} / \mathrm{cm}^{3}(\mathrm{SD}=0.02)$ of intermediate wood, and $0.46 \mathrm{~g} /$ $\mathrm{cm}^{3}(\mathrm{SD}=0.02)$ of sapwood. The average bulk densities of hemlock were $0.46 \mathrm{~g} / \mathrm{cm}^{3}(\mathrm{SD}=0.03)$ of heartwood, $0.40 \mathrm{~g} / \mathrm{cm}^{3}(\mathrm{SD}=0.02)$ of intermediate wood, and $0.41 \mathrm{~g} /$ $\mathrm{cm}^{3}(\mathrm{SD}=0.02)$ of sapwood.

The average true densities of hinoki sawdust were $1.53 \mathrm{~g} / \mathrm{cm}^{3}$ of heartwood and $1.43 \mathrm{~g} / \mathrm{cm}^{3}$ of sapwood; those of the cylindrical specimens were $1.35 \mathrm{~g} / \mathrm{cm}^{3}$ $(\mathrm{SD}=0.03)$ of heartwood, $1.35 \mathrm{~g} / \mathrm{cm}^{3}(\mathrm{SD}=0.02)$ of intermediate wood, and $1.39 \mathrm{~g} / \mathrm{cm}^{3}(\mathrm{SD}=0.03)$ of sapwood. The average true densities of Douglas fir sawdust were $1.42 \mathrm{~g} / \mathrm{cm}^{3}$ of heartwood and $1.53 \mathrm{~g} / \mathrm{cm}^{3}$ of sapwood, while those of the cylindrical specimen were $1.08 \mathrm{~g} / \mathrm{cm}^{3}(\mathrm{SD}=0.01)$ for heartwood, $1.26 \mathrm{~g} /$ $\mathrm{cm}^{3}(\mathrm{SD}=0.05)$ for intermediate wood, and $1.48 \mathrm{~g} / \mathrm{cm}^{3}$ $(\mathrm{SD}=0.23)$ for sapwood. The average true densities of hemlock sawdust were $1.52 \mathrm{~g} / \mathrm{cm}^{3}$ for heartwood and $1.40 \mathrm{~g} / \mathrm{cm}^{3}$ for sapwood, while those of the cylindrical specimen were $1.26 \mathrm{~g} / \mathrm{cm}^{3}(\mathrm{SD}=0.10)$ for heartwood, $1.25 \mathrm{~g} / \mathrm{cm}^{3}(\mathrm{SD}=0.01)$ for intermediate wood, and $1.28 \mathrm{~g} / \mathrm{cm}^{3}$ (SD =0.04) for sapwood.

It seems that the difference of true density between heartwood and sapwood in sawdust is caused by difference in extractive content. Further, true density tends to decrease when moving away from heartwood toward sapwood mainly due to the decrease in closed pore porosity.

\section{Results of gas permeability}

As shown in Fig. 5, the average Darcy permeability constants for hinoki were $0.547(\mathrm{SD}=0.071)$ for heartwood, $0.718(\mathrm{SD}=0.091)$ for intermediate wood, and $0.768(\mathrm{SD}=0.101)$ for sapwood. The permeability of sapwood was 1.4 times higher than that of heartwood $[p<0.05$ by Tukey's test (ANOVA)]. The average Darcy permeability constants of Douglas fir were 0.039 ( $\mathrm{SD}=0.010)$ for heartwood, 0.321 ( $\mathrm{SD}=0.154)$ for intermediate wood, and 0.542 (SD =0.174) for sapwood. The permeability for sapwood was 13.9 times greater than that of heartwood [ $p<0.01$ by Tukey's test (ANOVA)]. The average Darcy permeability constants of hemlock were $0.175(\mathrm{SD}=0.027)$ for heartwood, $1.021(\mathrm{SD}=0.506)$ for intermediate wood, and 1.307 $(\mathrm{SD}=0.270)$ for sapwood. The permeability of sapwood is 7.5 times greater than that of heartwood $[p<0.01$ by Tukey's test (ANOVA)]. The difference in permeability between heartwood and sapwood in the Douglas fir is due to their large diameter and old age compared to those of the other woods.

In all three softwoods, the permeability of sapwood was greater than that of heartwood, in agreement with prior studies [2, 20, 22]. The morphological pore characteristics of heartwood and sapwood were not significantly different, while the variance of gas permeability was high. SEM could observe only the cross-sectional surface of tracheid and could not observe the internal pathway. Hence, it is not feasible to predict the permeability of wood in the longitudinal direction by morphological observation of a cross-sectional surface of wood by SEM. 


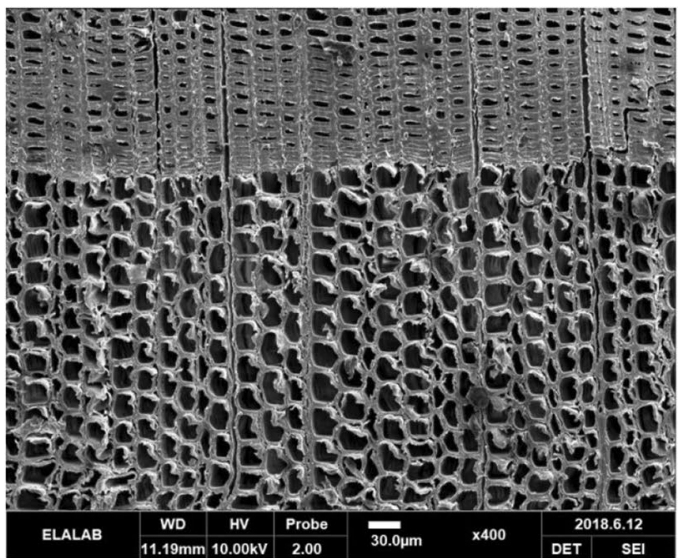

a Heartwood of Hinoki

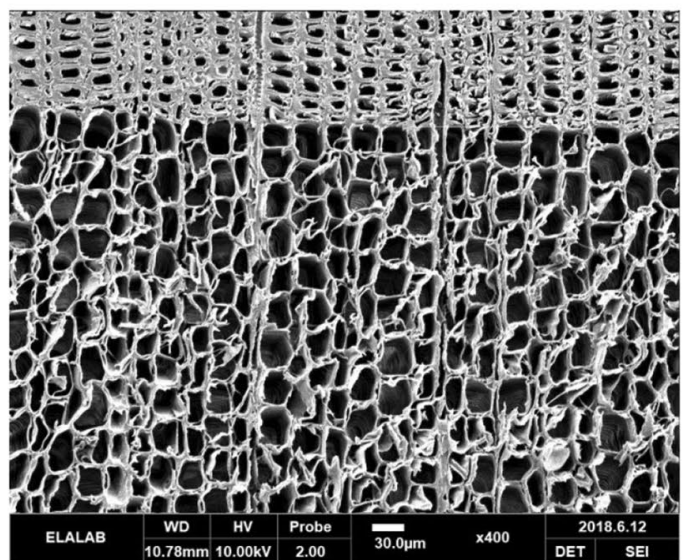

c Heartwood of Douglas-fir

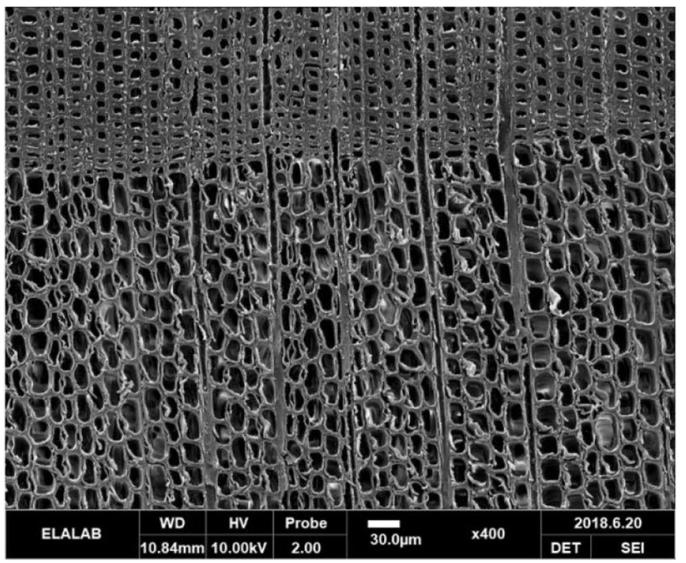

e Heartwood of Hemlock

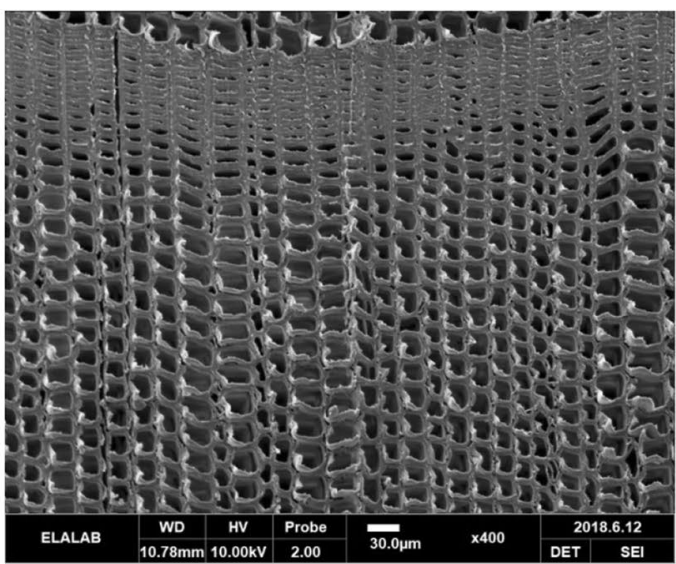

b Sapwood of Hinoki

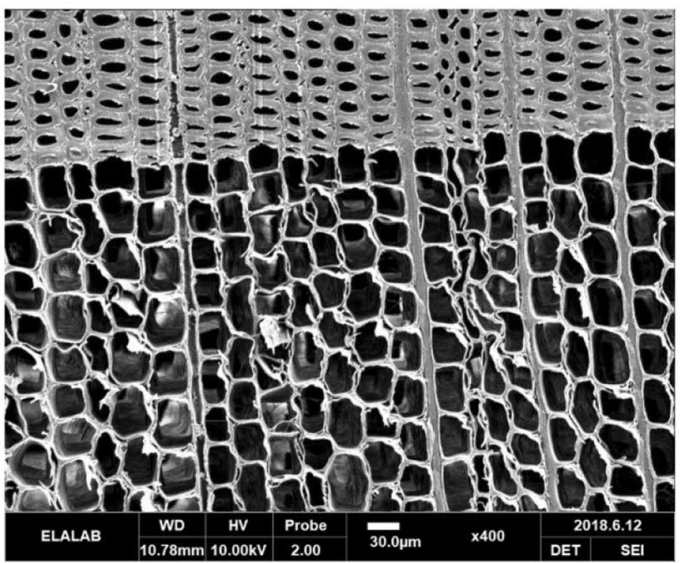

d Sapwood of Douglas-fir

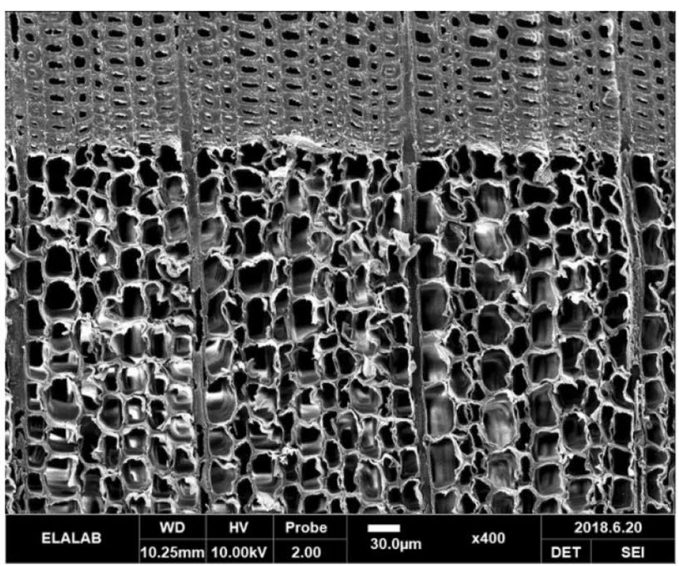

f Sapwood of Hemlock

Fig. 4 SEM images of cross-sections in three species of softwood 

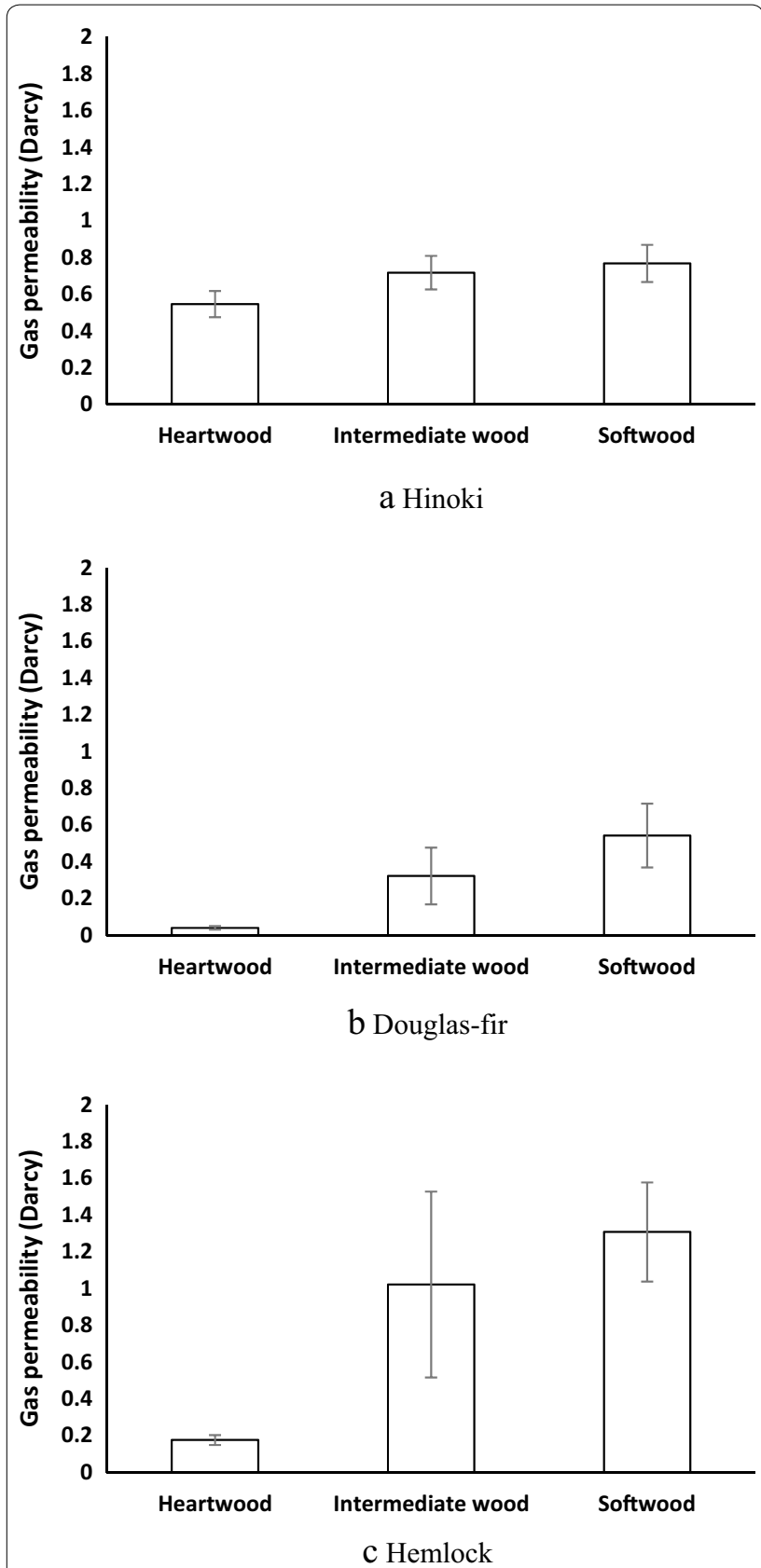

Fig. 5 Results of gas permeability of heartwood, intermediate wood and sapwood in three species of softwood (error bar; standard deviation)

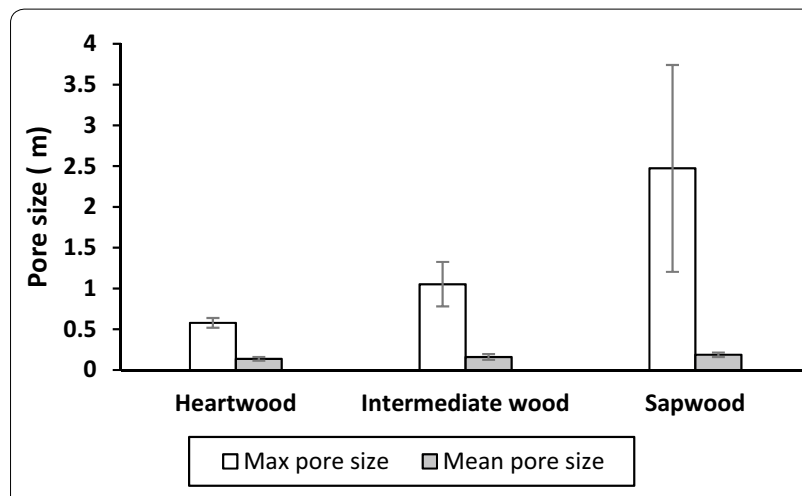

a Hinoki
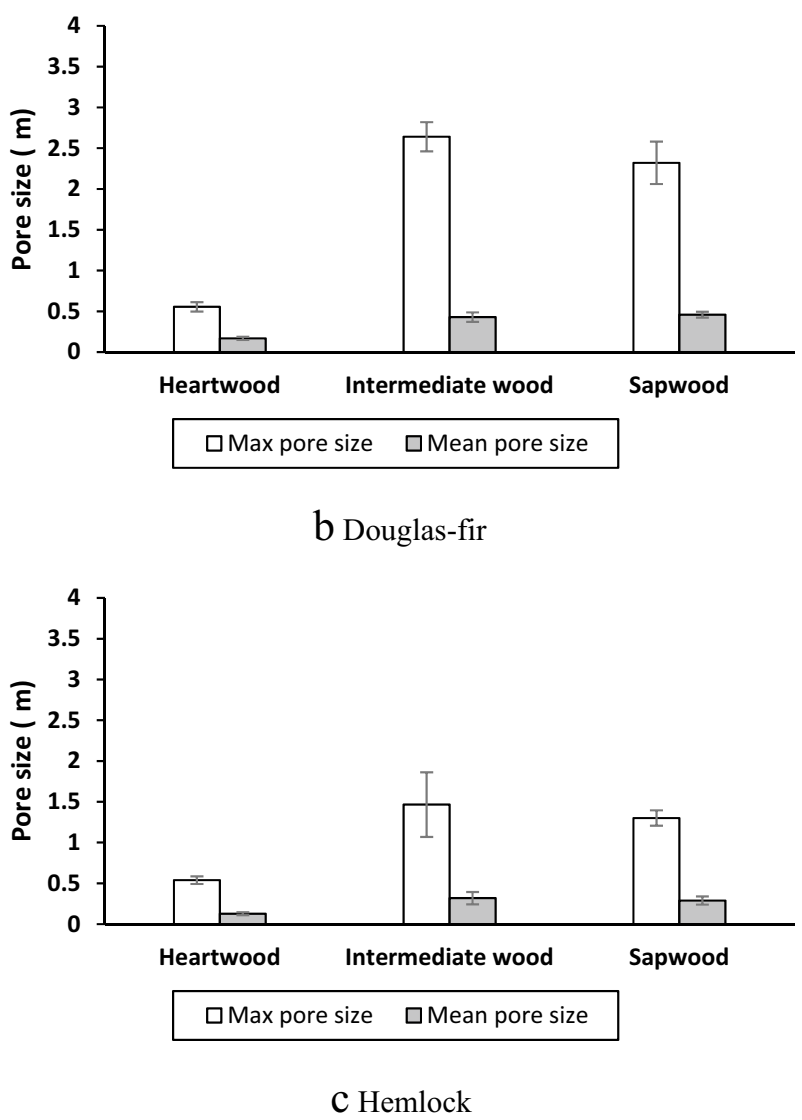

Fig. 6 Results of through pore size of heartwood, intermediate wood and sapwood in three species of softwood (error bar; standard deviation)

intermediate wood, and $2.47(\mathrm{SD}=1.27)$ of sapwood, for which the size was about 4.3 times greater than that of heartwood $[p<0.01$ by Tukey's test (ANOVA)]. Mean flow pore sizes for heartwood was $0.14 \mu \mathrm{m}(\mathrm{SD}=0.02)$, $0.16(\mathrm{SD}=0.04)$ for intermediate wood and 0.18 $(\mathrm{SD}=0.03)$ for sapwood, which was about 1.3 times larger than that of heartwood $[p<0.01$ by Tukey's test
As shown in Fig. 6, maximum pore sizes of hinoki were $0.58 \mu \mathrm{m}(\mathrm{SD}=0.06)$ for heartwood, $1.05(\mathrm{SD}=0.27)$ for

\section{Results of through pore diameter} consists of the constricted part of the through pore. In a cross-section of softwood, the through pore is tracheid, and the constricted part is margo pit membrane. 
(ANOVA)]. Maximum pore sizes of Douglas fir were $0.55 \mu \mathrm{m}(\mathrm{SD}=0.06)$ of heartwood, 2.64 $(\mathrm{SD}=0.18)$ of intermediate wood, and $2.32(\mathrm{SD}=0.26)$ for sapwood, which was about 4.2 times larger than that of heartwood $[p<0.01$ by Tukey's test (ANOVA)]. Mean flow pore sizes for heartwood were $0.17 \mu \mathrm{m}(\mathrm{SD}=0.02)$ for heartwood, $0.43(\mathrm{SD}=0.06)$ for intermediate wood, and $0.46(\mathrm{SD}=0.04)$ for sapwood, which was about 2.7 times greater than that of heartwood $[p<0.01$ by Tukey's test (ANOVA)]. Maximum pore sizes of hemlock were $0.54 \mu \mathrm{m}(\mathrm{SD}=0.05)$ for heartwood, $1.47(\mathrm{SD}=0.40)$ for intermediate wood, and $1.31(\mathrm{SD}=0.10)$ for sapwood, which was about 2.4 times larger than that of heartwood $[p<0.01$ by Tukey's test (ANOVA)]. Mean flow pore sizes for heartwood were $0.19 \mu \mathrm{m}(\mathrm{SD}=0.02), 0.32$ for intermediate wood, and $0.29(\mathrm{SD}=0.05)$ for sapwood, which was about 2.3 times larger than that of heartwood $[p<0.01$ by Tukey's test (ANOVA)]. Thus, pore sizes of sapwood were greater than those of heartwood in all three softwoods.

The pore size results in this study are similar to the range of softwood in previous studies [42-44].

\section{Porosity analysis (through pore, blind pore, and closed pore)}

As shown in Fig. 7, through pore porosity of hinoki were 46.58\% ( $\mathrm{SD}=1.66$ ) for heartwood, 46.34 ( $\mathrm{SD}=2.95)$ for intermediate wood, and $46.59(\mathrm{SD}=1.79)$ for sapwood. Through pore porosity of heartwood was lower than that of the sapwood [ $p<0.05$ by Tukey's test (ANOVA)]. Through pore porosities of Douglas fir were $15.62 \%$ $(\mathrm{SD}=1.63)$ for heartwood, $34.25(\mathrm{SD}=5.32)$ for intermediate wood, and $44.94(\mathrm{SD}=2.10)$ for sapwood. Through pore porosity of sapwood was 2.9 times higher than that of heartwood [ $p<0.01$ by Tukey's test (ANOVA)]. Through pore porosities of hemlock were $30.15 \%$ $(\mathrm{SD}=3.12)$ for heartwood, $39.46(\mathrm{SD}=2.96)$ for intermediate wood, and $42.30(\mathrm{SD}=2.04)$ for sapwood. Through porosity of sapwood was 1.4 times higher than that of heartwood $[p<0.01$ by Tukey's test (ANOVA)]. In softwoods hinoki, Douglas fir, and hemlock, through pore porosity of heartwood was reduced.

Pit aspirations of tracheid in the heartwood are in the form of blind pore or closed pore, resulting in lower through pore porosity in heartwood than sapwood.

\section{Correlation and regression results}

Table 1 presents the results of Pearson correlation analysis among the variables. Gas permeability showed a highly positive relationship with through pore porosity. $(0.709)$ at a $1 \%$ level of significance and a negative trend with bulk density $(-0.258)$ at a $5 \%$ level of significance. These results indicate that, as through pore porosity

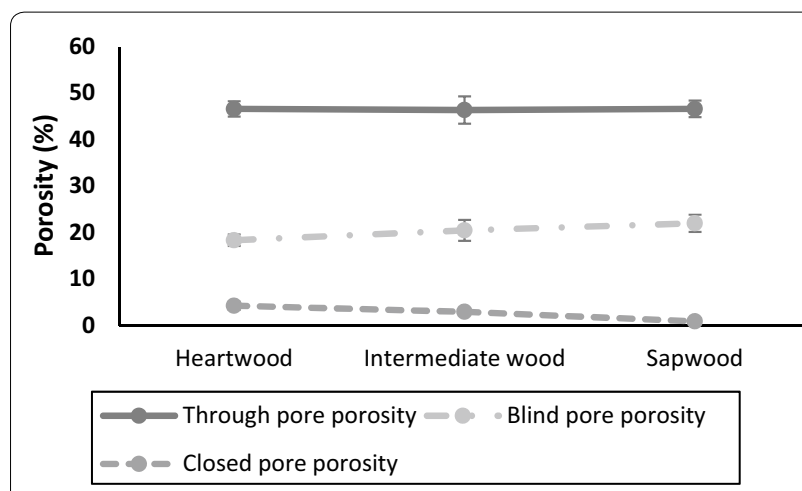

a Hinoki

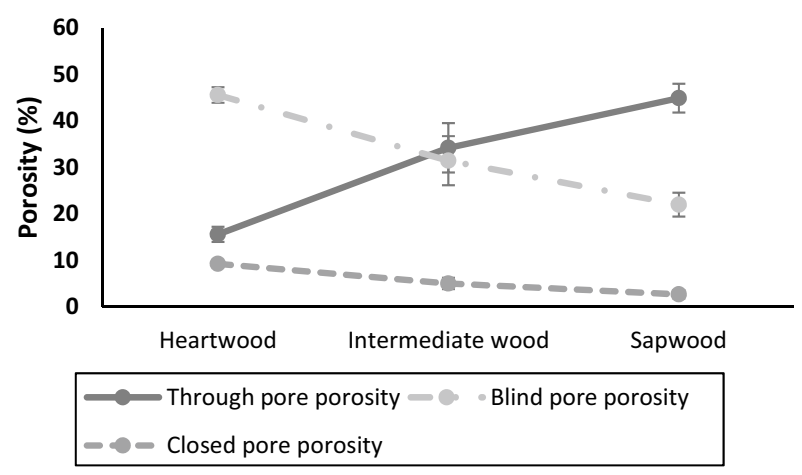

b Douglas-fir

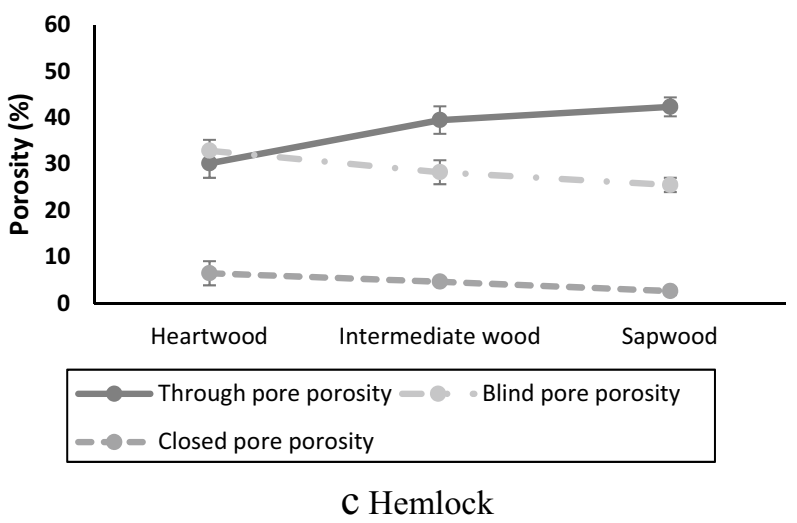

Fig. 7 Results of porosity analysis of heartwood, intermediate wood and sapwood in three species of softwood (error bar; standard deviation)

increases, gas permeability also increases. However, as bulk density increases, gas permeability decreases. No significant relation was found between mean pore size and gas permeability. Table 1 shows that the multi-collinearity problem in regression analysis was not significant because the correlations among the independent 
Table 1 Results of Pearson correlation analysis $(n=90)$

\begin{tabular}{|c|c|c|c|c|}
\hline & $Y$ & $X_{1}$ & $X_{2}$ & $X_{3}$ \\
\hline Y & - & $0.709^{* *}$ & 0.178 & -0.258 \\
\hline$X_{1}$ & & - & 0.113 & $0.252^{*}$ \\
\hline$x_{2}$ & & & - & -0.188 \\
\hline$x_{3}$ & & & & - \\
\hline
\end{tabular}

variables (porosity, pore size, and density) were statistically weak or not significant.

Table 2 shows the regression results with Eq. (9). Panels A, B, and C present estimated results of Eq. (9) with each independent variables, and Panel D shows estimated results of regression with all independent variables. All estimated coefficients of porosity $\left(\beta_{1}\right)$ and pore size $\left(\beta_{2}\right)$ were positively significant at a $1 \%$ level in Panels $\mathrm{A}, \mathrm{B}$, and $\mathrm{D}$. In addition, estimated coefficients of density $\left(\beta_{3}\right)$ were negatively significant at a $1 \%$ level in Panels $C$ and $D$. These results suggest that an increase of through pore porosity and mean pore size as well as a decrease of bulk density substantially increase gas permeability. All $F$-values of Panels A, B, C, and D were significant at a $1 \%$ level, indicating goodness-of-fit for the estimated regression results. Most adj. $R^{2}$ s were above $60 \%$, especially that of $78.40 \%$ in Panel D. Hence, the explanatory power of the regression model was also acceptable. All VIFs (variance inflation factor) in Panel D were less than 10, which suggests multi-collinearity was not significant.

The results of Table 2 represent the three species (hinoki, Douglas fir, and hemlock) of softwood and should not be applied to other softwood species. They can be developed into a forecasting model after including and analyzing more species of softwood.

\section{Conclusions}

Summary of the results of the experiments on permeability and pore structure of heartwood and sapwood is as follows:

1. SEM was used to observe the cross-section of the wood and confirmed that the pore was slightly smaller in heartwood compared to sapwood. However, the difference was not significant, so we could not analyze detailed pore structure from heartwood to sapwood.

2. The gas permeability of hinoki, Douglas fir, and hemlock increased from heartwood to sapwood.

3. The pore structures of softwood was classified into through pore, blind pore, and closed pore following IUPAC definitions and observed using capillary flow porometer and gas pycnometer. Through pore porosity tended to increase from heartwood to sapwood.

4. Capillary flow porometry was used to evaluate pore size on the cross-sectional surface of the wood and showed that maximum pore size and mean flow pore size of sapwood were greater than those of heartwood.

5. Through pore porosity, mean pore size, and bulk density were the main factors affecting gas permeability in multivariate regression analysis.

Type of pore is related to permeability of the wood, and the quantity of pores affect drying, processing, and modifying of woods.

\section{Abbreviations}

$\varphi_{\text {total }}$ Total porosity; $\varphi_{\text {through: }}:$ Through pore porosity; $\varphi_{\text {blind: }}$ : Blind pore porosity; $\varphi_{\text {closed }}:$ Closed pore porosity; $V_{\text {true: }}:$ True volume; $V_{\text {bulk: }}$ Bulk volume; $V_{\text {through }}$ : Through pore volume; $V_{\text {blind }}$ : Blind pore volume; $M_{\text {after extrusion: }}$ Difference in specimen mass after extrusion; $M_{\text {dried: }}$ : Dried specimen mass; $\rho_{\text {bulk: }}$ : Bulk density; $\rho_{\text {Galwick: }}$ Specific gravity of Galwick solution; $a_{0}$ : Constant (intercept term); $\varepsilon$ :

Table 2 Results of regression $(n=90)$

\begin{tabular}{|c|c|c|c|c|c|c|c|c|c|}
\hline \multirow[t]{2}{*}{ Variables } & \multicolumn{2}{|c|}{ Panel A } & \multicolumn{2}{|l|}{ Panel B } & \multicolumn{2}{|l|}{ Panel C } & \multicolumn{3}{|l|}{ Panel D } \\
\hline & Coef. & t-stat. & Coef. & $t$-stat. & Coef. & $t$-stat. & Coef. & $t$-stat. & VIF \\
\hline Intercept & $-0.449^{*}$ & -3.688 & $0.186^{*}$ & 2.931 & $2.510^{*}$ & 5.016 & $1.568^{*}$ & 5.232 & \\
\hline$x_{1}$ & $3.000^{*}$ & 9.582 & - & - & - & - & $2.251^{*}$ & 5.856 & 4.082 \\
\hline$x_{2}$ & - & - & $1.955^{*}$ & 9.135 & - & - & $0.736^{*}$ & 2.869 & 4.017 \\
\hline$x_{3}$ & - & - & - & - & $-4.316^{*}$ & -3.692 & $-4.505^{*}$ & -6.527 & 1.265 \\
\hline$D_{1}, D_{2}$ & Included & & Included & & Included & & Included & & \\
\hline $\operatorname{adj} . R^{2}$ & $64.10 \%$ & & $63.60 \%$ & & $35.90 \%$ & & $78.40 \%$ & & \\
\hline F-value & 53.966 & & 50.076 & & 17.632 & & 65.543 & & \\
\hline$p$-value & $<0.001$ & & $<0.001$ & & $<0.001$ & & $<0.001$ & & \\
\hline
\end{tabular}

* Represents significance at 1 percent level. Denotations of variables are the same as in Table 1 
Residuals (error term); ANOVA: Analysis of variance; IUPAC: International Union of Pure and Applied Chemistry; MC: Moisture content; SD: Standard deviation; $Y$ : Gas permeability; $X_{1}$ : Through pore porosity; $X_{2}$ : Mean pore size; $X_{3}$ : Bulk density; $D_{1}$ : Wood dummy variable ( 1 : if the wood is hinoki, otherwise 0$) ; D_{2}$ : Wood dummy variable ( 1 if the wood is Douglas fir, otherwise 0); OLS: Ordinary least square; VIF: Variance inflation factor.

\section{Acknowledgements}

This research was supported by Basic Science Research Program through the National Research Foundation of Korea (NRF) funded by the Ministry of Education (NRF-2019R111 A3A02059471) and was supported under the framework of international cooperation program managed by the NRF of Korea (NRF2020K2A9A2A08000181). Authors also thankful to the "Leaders in IndustryUniversity Cooperation + Project", supported by the Ministry of Education and NRF of Korea. This manuscript is a revision of the first author's master's thesis from Jeonbuk National University. We thank Richard Hanzlik from Alpha Technologies, USA, for assistance with English writing.

\section{Authors' contributions}

ESJ was a major contributor in the writing of this manuscript as well as the design of experiment. JHY designed, performed, and interpreted all statistical analyses and results. CWK contributed to data analysis and to discussion of the obtained results. All authors read and approved the final manuscript.

\section{Funding}

No funding.

\section{Availability of data and materials}

Not applicable.

\section{Competing interests}

The authors declare that they have no competing interests.

\section{Author details}

1 Department of Housing Environmental Design, and Research Institute of Human Ecology, College of Human Ecology, Jeonbuk National University, Jeonju 54896, South Korea. ${ }^{2}$ College of General Education, Chung-Ang University, Seoul 06974, South Korea.

Received: 3 March 2020 Accepted: 28 October 2020 Published online: 07 November 2020

\section{References}

1. Petty J, Puritch $G$ (1970) The effects of drying on the structure and permeability of the wood of Abies grandis. Wood Sci Technol 4(2):140-154

2. Hur J-Y, Kang H-Y (1997) Measurement of longitudinal liquid permeability using pressure bomb method. J Korean Wood Sci Technol 25(3):66-74

3. Kang C-W, Li C, Jang E-S, Jang S-S, Kang H-Y (2018) Changes in sound absorption capability and air permeability of Malas (Homalium foetidum) specimens after high temperature heat treatment. J Korean Wood Sci Technol 46(2):149-154

4. Esmailpour A, Taghiyari HR, Golchin M, Avramidis S (2019) On the fluid permeability of heat treated paulownia wood. Int Wood Prod J 10(2):55-63

5. Jang E-S, Kang C-W (2019) Changes in gas permeability and pore structure of wood under heat treating temperature conditions. J Wood Sci 65(1):1-9

6. Taghiyari HR, Avramidis S (2019) Specific gas permeability of normal and nanosilver-impregnated solid wood species as influenced by heat-treatment. Maderas Ciencia y Tecnología 21(1):89-96

7. Taghiyari HR (2013) Nano-zycosil in MDF: gas and liquid permeability. Eur J Wood Wood Prod 71(3):353-360

8. Taghiyari HR, Kalantari A, Ghorbani M, Bavaneghi F, Akhtari M (2015) Effects of fungal exposure on air and liquid permeability of nanosilver- and nanozincoxide-impregnated Paulownia wood. Int Biodeterior Biodegrad 105:51-57

9. Kang C-W, Kim G-C, Park H-J, Lee N-H, Kang W, Matsumura J (2010) Changes in permeability and sound absorption capability of yellow poplar wood by steam explosion treatment. J Fac Agric Kyushu Univ 55(2):327-332

10. Kang C-W, Jang E-S, Jang S, Kang H-Y, Li C, Choi I-G (2018) Changes of air permeability and moisture absorption capability of the wood by organosolv pretreatment. J Korean Wood Sci Technol 46(6):637-644

11. Kang C-W, Lee Y-H, Kang H-Y, Kang W, Xu H, Chung W-Y (2011) Radial variation of sound absorption capability in the cross sectional surface of yellow poplar wood. J Korean Wood Sci Technol 39(4):326-332

12. Taghiyari HR, Habibzade S, Miri Tari SM (2014) Effects of wood drying schedules on fluid flow in Paulownia wood. Drying Technol 32(1):89-95

13. Booker R, Evans J (1994) The effect of drying schedule on the radial permeability of Pinus radiata D. Don. HOLZ als Roh-und Werkstoff 52(3):150-156

14. Taghiyari HR, Ghorbani M, Kalantari A (2013) Effects of silver and copper nanoparticles on gas and liquid permeability of heat-treated solid woods. Spec Top Rev Porous Media 4(1):81-97

15. Taghiyari HR, Malek BM (2014) Effect of heat treatment on longitudinal gas and liquid permeability of circular and square-shaped native hardwood specimens. Heat Mass Transf 50(8):1125-1136

16. Taghiyari H, Zolfaghari H, Sadeghi M, Esmailpour A, Jaffari A (2014) Correlation between specific gas permeability and sound absorption coefficient in solid wood. J Trop For Sci 26:92-100

17. Kang C, Kang W, Chung W, Matsumura J, Oda K (2008) Changes in anatomical features, air permeability and sound absorption capability of wood induced by delignification treatment. J Fac Agric Kyushu Univ 53(2):479-483

18. Côté WA, Kollmann FF (1984) Principles of wood science and technology. I solid wood. Springer, Berlin

19. Bamber R (1987) Sapwood and heartwood. Beecroft, Australie, Forestry Commission of New South Wales. Wood Technology and Forest Research Division, Technical Publication, vol 2. Wood Technology and Forest Research Division, Australia

20. Fogg $P$ (1969) Longitudinal air permeability of four species of southern pine wood. Wood Sci 2(1):35-43

21. Stamm AJ (2007) Maximum effective pit pore radii of the heartwood and sapwood of six softwoods as affected by drying and resoaking. Wood Fiber Sci 1(4):263-269

22. Chen PY, Tang Y (1991) Variation in longitudinal permeability of three US hardwoods. For Prod J 41(11-12):79-83

23. Rice RW, D'Onofrio M (2007) Longitudinal gas permeability measurements from eastern white pine, red spruce, and balsam fir. Wood Fiber Sci 28(3):301-308

24. Leggate W, Redman A, Wood J, Bailleres H, Lee DJ (2019) Radial permeability of the hybrid Pine (Pinus elliottii $\times$ Pinus caribaea) in Australia. BioResources 14(2):4358-4372

25. Timell TE (2014) Compression wood in gymnosperms. Springer, Berlin

26. Dietrich Fengel GW (1989) Wood: chemistry, ultrastructure, reactions. Walter de Gruyter, Berlin

27. Chen CL (1991) Lignins: occurrence in woody tissues, isolation, reactions and structure. In: Lewin M, Goldstein IS (eds) Wood structure and composition. Marcel Dekker, New York

28. Olsson T, Megnis M, Varna J, Lindberg H (2001) Study of the transverse liquid flow paths in pine and spruce using scanning electron microscopy. J Wood Sci 47(4):282-288

29. Ekeberg D, Flæte P-O, Eikenes M, Fongen M, Naess-Andresen CF (2006) Qualitative and quantitative determination of extractives in heartwood of Scots pine (Pinus sylvestris L.) by gas chromatography. J Chromatogr A 1109(2):267-272

30. Baraúna EEP, Lima JT, Vieira RdS, Silva JRMd, Monteiro TC (2014) Effect of anatomical and chemical structure in the permeability of "Amapá" wood. Cerne 20(4):529-534

31. Comstock GL (1965) Longitudinal permeability of green eastern hemlock. For Prod J 15(10):441-449

32. Erickson H (1970) Permeability of Southern Pine wood - a review. Wood Sci 2(3):149-158

33. Zimmer KP, Høibø OA, VestøI GI, Larnøy E (2014) Variation in treatability of Scots pine sapwood: a survey of 25 different northern European locations. Wood Sci Technol 48(5):1049-1068

34. Schneider A, Wagner L (1974) Bestimmung der Porengrößenverteilung in Holz mit dem Quecksilber-Porosimeter. HOLZ als Roh-und Werkstoff 32(6):216-224 
35. Plötze M, Niemz P (2011) Porosity and pore size distribution of different wood types as determined by mercury intrusion porosimetry. Eur J Wood Wood Prod 69(4):649-657

36. Jang E-S, Kang C-W, Jang S-S (2018) Comparison of the mercury intrusion porosimetry, capillary flow porometry and gas permeability of eleven species of Korean wood. J Korean Wood Sci Technol 46(6):681-691

37. Jang E-S, Kang C-W, Jang S-S (2019) Pore characterization in cross section of yellow poplar (Liriodendron tulipifera) wood. J Korean Wood Sci Technol 47(1):8-20

38. Wu G, Shah DU, Janeček E-R, Burridge HC, Reynolds TP, Fleming PH, Linden P, Ramage $\mathrm{MH}$, Scherman OA (2017) Predicting the pore-filling ratio in lumen-impregnated wood. Wood Sci Technol 51(6):1277-1290

39. ASTM F316-03 (2019) Standard test methods for pore size characteristics of membrane filters by bubble point and mean flow pore test (2019). ASTM International, West Conshohocken

40. Jena A, Gupta K (2002) Characterization of pore structure of filtration media. Fluid/Part Sep J 14(3):227-241
41. Rouquerol J, Avnir D, Fairbridge C, Everett D, Haynes J, Pernicone N, Ramsay J, Sing K, Unger K (1994) Recommendations for the characterization of porous solids (Technical Report). Pure Appl Chem 66(8):1739-1758

42. Petty J, Preston RD (1969) The dimensions and number of pit membrane pores in conifer wood. Proc R Soc Lond Ser B Biol Sci 172(1027):137-151

43. Cochard H, Hölttä T, Herbette S, Delzon S, Mencuccini M (2009) New insights into the mechanisms of water-stress-induced cavitation in conifers. Plant Physiol 151(2):949-954

44. Jansen S, Lamy JB, Burlett R, Cochard H, Gasson P, Delzon S (2012) Plasmodesmatal pores in the torus of bordered pit membranes affect cavitation resistance of conifer xylem. Plant Cell Environ 35(6):1109-1120

\section{Publisher's Note}

Springer Nature remains neutral with regard to jurisdictional claims in published maps and institutional affiliations.

\section{Submit your manuscript to a SpringerOpen ${ }^{\circ}$ journal and benefit from:}

- Convenient online submission

- Rigorous peer review

- Open access: articles freely available online

- High visibility within the field

- Retaining the copyright to your article

Submit your next manuscript at $\boldsymbol{\nabla}$ springeropen.com 